\title{
The Effects of Low and High Tidal Volume and Pentoxifylline on Intestinal Blood Flow and Leukocyte-Endothelial Interactions in Mechanically Ventilated Rats
}

\author{
Priscila Aikawa PT PhD, Haibo Zhang MD PhD, Carmen SV Barbas MD PhD, \\ Rogério Pazetti PhD, Cristiano Correia, Thaís Mauad MD PhD, Eliézer Silva MD PhD, \\ Paulina Sannomiya MSc PhD, Luiz F Poli-de-Figueiredo MD PhD, \\ and Naomi Kondo Nakagawa PT MSc PhD
}

\begin{abstract}
BACKGROUND: The combination of high PEEP and low tidal volume $\left(V_{T}\right)$ decreases some risks of mechanical ventilation, including pulmonary overdistention, damage due to cyclic opening and closing of the alveoli, and inflammatory responses that can lead to multiple-organ dysfunction. We hypothesized that high $V_{T}$ and high PEEP induce mesenteric microcirculatory disturbances and that those disturbances would be attenuated by pentoxifylline, which is anti-inflammatory. METHODS: We anesthetized (isoflurane 1.5\%), tracheostomized, and mechanically ventilated 57 male Wistar rats with PEEP of $10 \mathrm{~cm} \mathrm{H}_{2} \mathrm{O}$ and $\mathrm{F}_{\mathrm{IO}_{2}}$ of 0.21 for 2 hours. One group received low $\mathrm{V}_{\mathrm{T}}$ $(7 \mathrm{~mL} / \mathrm{kg})$, another group received high $V_{T}(10 \mathrm{~mL} / \mathrm{kg})$, and a third group received high $V_{T}$ plus pentoxifylline $(25 \mathrm{mg} / \mathrm{kg})$. We measured mean arterial pressure, respiratory mechanics, mesenteric blood flow, and leukocyte-endothelial interactions. RESULTS: The mean arterial pressure was similar among the groups at baseline $(108 \mathrm{~mm} \mathrm{Hg}$ [IQR 94-118 mm Hg]) and after 2 hours of mechanical ventilation (104 mm Hg [IQR 90-114 mm Hg]). Mesenteric blood flow was also similar between the groups: low $V_{T} 15.1 \mathrm{~mL} / \mathrm{min}$ (IQR 12.4-17.7 mL/min), high $V_{T} 11.3 \mathrm{~mL} / \mathrm{min}(I Q R ~ 8.6-$ $13.8 \mathrm{~mL} / \mathrm{min})$, high- $\mathrm{V}_{\mathrm{T}} /$ pentoxifylline $12.4 \mathrm{~mL} / \mathrm{min}(10.8-13.7 \mathrm{~mL} / \mathrm{min})$. Peak airway pressure after 2 hours was lower $(P=.03)$ in the low- $\mathrm{V}_{\mathrm{T}}$ group $\left(10.4 \mathrm{~cm} \mathrm{H}_{2} \mathrm{O}\right.$ [IQR 10.2-10.4 $\left.\left.\mathrm{cm} \mathrm{H}_{2} \mathrm{O}\right]\right)$ than in the high- $\mathrm{V}_{\mathrm{T}}$ group $\left(12.6 \mathrm{~cm} \mathrm{H}_{2} \mathrm{O}\left[10.2-14.9 \mathrm{~cm} \mathrm{H}_{2} \mathrm{O}\right]\right)$ or the high- $\mathrm{V}_{\mathrm{T}} /$ pentoxifylline group $\left(12.8 \mathrm{~cm} \mathrm{H} \mathrm{H}_{2} \mathrm{O}\right.$ [10.7-16.0 $\left.\left.\mathrm{cm} \mathrm{H}_{2} \mathrm{O}\right]\right)$. There were fewer adherent leukocytes $(P=.005)$ and fewer migrated leukocytes $(P=.002)$ in the low- $V_{T}$ group $(5$ cells $/ 100 \mu \mathrm{m}$ length $[I Q R ~ 4-7$ cells $/ 100 \mu \mathrm{m}$ length] and 1 cell/5,000 $\mu \mathrm{m}^{2}$ [IQR 1-2 cells $\left./ 5,000 \mu \mathrm{m}^{2}\right]$, respectively) and the high- $\mathrm{V}_{\mathrm{T}} /$ pentoxifylline group $\left(5\right.$ cells $/ 100 \mu \mathrm{m}$ length [IQR 3-10 cells/100 $\mu \mathrm{m}$ length] and 1 cell/5,000 $\mu^{2}{ }^{2}$ [IQR 1-3 cells/ $5,000 \mathrm{~mm}^{2}$ ], respectively) than in the high- $V_{T}$ group $(14$ cells/100 $\mu \mathrm{m}$ length [IQR 11-16 cells/ $100 \mu \mathrm{m}$ length] and 9 cells $/ 5,000 \mu \mathrm{m}^{2}$ [IQR 8-12 cells $\left./ 5,000 \mu \mathrm{m}^{2}\right]$, respectively). CONCLUSIONS: Low $V_{T}$ with high PEEP was lung-protective, and early pentoxifylline reduced the inflammatory response to high $\mathbf{V}_{T}$ with high PEEP (and presumed lung overdistention) during mechanical ventilation. Key words: mechanical ventilation; pentoxifylline; PEEP; leukocyte-endothelial interactions; intravital microscopy; ventilator-induced lung injury; tidal volume; mesentery. [Respir Care 2011;56(12): 1942-1949. (C) 2011 Daedalus Enterprises]
\end{abstract}

\footnotetext{
Dr Aikawa, Dr Pazetti, Mr Correia, and Dr Sannomiya are affiliated with the Department of Cardiopneumology; Dr Aikawa and Dr Nakagawa are affiliated with the Department of Physiotherapy, Communication Science and Disorders, and Occupational Therapy; Dr Barbas is affiliated with the Pneumology Division; Dr Mauad is affiliated with the Department of Pathology; and Dr Silva and Dr Poli-deFigueiredo are affiliated with the Department of Surgery, Faculdade de Medicina da Universidade de São Paulo, São Paulo, Brazil. Dr Zhang is affiliated with the Department of Anesthesiology, Saint-Michael Hospital, University of Toronto, Toronto, Ontario, Canada.
}

\begin{abstract}
This study was partly supported by grant FAPESP 07/51605-9 from Fundação de Amparo à Pesquisa do Estado de São Paulo, São Paulo, Brazil. The authors have disclosed no other conflicts of interest.

Correspondence: Naomi Kondo Nakagawa PT MSc PhD, Department of Physiotherapy, Communication Science and Disorders, and Occupational Therapy, Faculdade de Medicina da Universidade de São Paulo, LIM 34, Avenue Dr Arnaldo, 455 Room 1150, Cerqueira Cesar CEP, 01246-903 São Paulo, Brazil. E-mail: naomi.kondo@usp.br.
\end{abstract}

DOI: $10.4187 /$ respcare. 01183 


\section{Low and High Tidal Volume Versus Pentoxifylline in Mechanically Ventilated Rats}

\section{Introduction}

PEEP during mechanical ventilation is believed to improve oxygenation. The combination of high PEEP and low tidal volume $\left(\mathrm{V}_{\mathrm{T}}\right)$ during mechanical ventilation is a protective strategy that decreases the risk of pulmonary overdistention, damage due to cyclic opening and closing of the alveoli, and inflammatory responses that can lead to multiple-organ dysfunction. ${ }^{1-3}$ However, PEEP increases intrathoracic pressure, which can reduce venous return and cardiac output, and redistribute blood flow away from the splanchnic vasculature. ${ }^{4-6}$ Hypoperfusion and ischemia in the gastrointestinal tract are associated with loss of tract barrier and systemic inflammation, ${ }^{7}$ which may play a pivotal role in the pathogenesis of several complications associated with mechanical ventilation, ${ }^{8-10}$ including multiple-organ failure in patients with severe sepsis and cardiac failure, a situation that usually has a very poor outcome. ${ }^{11-13}$

Therapies directed at improving microcirculation and local/systemic cellular perfusion may improve outcomes. Pentoxifylline (pentoxifylline 1-(5-oxohexyl)-3,7-dimethylxanthine) is a methylxanthine derivative and a nonspecific phosphodiesterase-inhibitor associated with increased deformability of red blood cells ${ }^{14}$ and with reduced blood viscosity, ${ }^{15}$ which are 2 factors that might improve blood flow. Pentoxifylline improved the integrity and permeability of the gut barrier, bacterial translocation, neutrophil activation, endothelial dysfunction, blood flow, lung oxygenation, and overall survival in models of acute lung injury, ${ }^{16,17}$ hemorrhagic shock/reperfusion, ${ }^{18,19}$ and sepsis. ${ }^{20}$ In humans, pentoxifylline inhibited the production of tumor necrosis factor alpha in alveolar macrophages. ${ }^{21} \mathrm{In}$ contrast, in animal models of multiple-organ dysfunction ${ }^{22}$ and in patients with severe septic shock, ${ }^{23}$ pentoxifylline did not improve outcomes.

Intravital microscopy is a live-imaging technique used in animal models of hemorrhagic shock/reperfusion and sepsis. ${ }^{19,23-25}$ We recently found that injurious mechanical ventilation with a high $\mathrm{V}_{\mathrm{T}}(10 \mathrm{~mL} / \mathrm{kg})$ and a PEEP of $10 \mathrm{~cm} \mathrm{H}_{2} \mathrm{O}$ markedly increased leukocyte-endothelial interactions in rat mesentery. ${ }^{26}$ Lung-protective ventilation is the only treatment that has been shown to decrease mortality in patients with ARDS. Because of the severity of the underlying disease, in many patients it is not possible to provide a ventilation strategy that will protect all lung units, so a pharmacologic therapy that modulates the inflammatory response would be beneficial. We investigated the effects of early pentoxifylline in mechanically ventilated rats.

\section{Methods}

This study was approved by and under the license of the Institutional Animal Care and Use Committee of the Heart
Institute, Faculdade de Medicina da Universidade de São Paulo, and was performed according to the United States National Institutes of Health guidelines for the use of experimental animals.

\section{Animals}

Fifty-seven adult male Wistar rats (mean \pm SD weight $253 \pm 27 \mathrm{~g}$ ) were housed for 3-5 d before the experiment, with unrestricted access to food and water. In the experiment the animals were first anesthetized with sodium pentobarbital (50 mg/kg, intraperitoneal), then we cannulated the right carotid artery and jugular vein with PE50 tubing, and tracheotomized with PE45 tubing for spontaneous breathing. We then randomly assigned the animals to 3 groups: low $\mathrm{V}_{\mathrm{T}}\left(\mathrm{V}_{\mathrm{T}}=7 \mathrm{~mL} / \mathrm{kg}\right)($ no. $=19)$, high $\mathrm{V}_{\mathrm{T}}$ $\left(\mathrm{V}_{\mathrm{T}}=10 \mathrm{~mL} / \mathrm{kg}\right)($ no. $=19)$, and high $\mathrm{V}_{\mathrm{T}}$ plus pentoxifylline $(25 \mathrm{mg} / \mathrm{kg})$ at the beginning of mechanical ventilation (no. = 19). We continued anesthesia with isoflurane $(1.5 \%)^{26}$ during the 2 hours of mechanical ventilation, with a PEEP of $10 \mathrm{~cm} \mathrm{H}_{2} \mathrm{O}$ on room air. The respiratory rate was set at 70 breaths/min in the high- $\mathrm{V}_{\mathrm{T}}$ and high$\mathrm{V}_{\mathrm{T}}$ /pentoxifylline groups, and at 80 breaths $/ \mathrm{min}$ in the low- $\mathrm{V}_{\mathrm{T}}$ group, to maintain normocapnia. All the animals received an infusion of saline ( $100 \mu \mathrm{L} / 100 \mathrm{~g}$ body weight).

\section{Hemodynamics Measurements}

At baseline and after 2 hours of mechanical ventilation we recorded blood pressure (MK-III-S, Narco Bio-Systems, Austin, Texas). Via laparotomy we gently dissected the superior mesenteric artery from the surrounding tissue and measured mesenteric artery blood flow with an ultrasound transit-time flow probe (2SB545, Transonic Systems, Ithaca, New York) placed around the artery.

\section{Respiratory Mechanics Measurements}

We collected data as previously reported, ${ }^{27}$ at the beginning of mechanical ventilation and after 2 hours of mechanical ventilation. We measured peak airway pressure $\left(\mathrm{P}_{\mathrm{aw}}\right)$ with a differential pressure transducer (142PC05D, Honeywell, Freeport, Illinois) connected to a side tap in the tracheal cannula. We measured air flow (ن) with a pneumotachograph (Fleish 4-0, OEM Medical, Richmont, Virginia) connected to the tracheal cannula and to a differential pressure transducer (163PC01D36, Honeywell, Freeport, Illinois). We measured lung-volume changes (V) via electronic integration of the $\dot{V}$ signal. We averaged 10 respiratory cycles for each data point. We 
calculated respiratory system elastance $\left(\mathrm{E}_{\mathrm{RS}}\right)$ and resistance $\left(\mathrm{R}_{\mathrm{RS}}\right)$ with the linear equation of motion:

$$
\mathrm{P}_{\mathrm{aw}}(\text { time })=\mathrm{E}_{\mathrm{RS}} \times \mathrm{V}(\text { time })+\mathrm{R}_{\mathrm{RS}} \times \dot{\mathrm{V}}(\text { time })
$$

which we fit to the $\mathrm{P}_{\mathrm{aw}}, \dot{\mathrm{V}}$, and $\mathrm{V}$ measurements with multiple linear regression. We acquired and analyzed the data with the ANADAT 4.0 software (RHT Info, Montreal, Canada).

\section{Blood Gas Analysis}

We conducted arterial blood gas analysis (ABL 555, Radiometer Medical, Copenhagen, Denmark) 5 min after beginning mechanical ventilation (baseline), and 2 hours after beginning mechanical ventilation.

\section{Intravital Microscopy of the Mesentery}

All the animals were kept under mechanical ventilation during intravital microscopy, as previously described. ${ }^{24-26}$ After midline abdominal incision, the distal ileum and its accompanying mesentery is exposed for examination of the microcirculation. The animal is placed in the right lateral decubitus on a warmed $\left(37^{\circ} \mathrm{C}\right)$ stage, and the mesentery is transilluminated and kept moist with continuous applications of warm $\left(37^{\circ} \mathrm{C}\right) \mathrm{Krebs}$ solution. Care is taken during handling to prevent physical damage. Mesenteric microcirculation is assessed after $10 \mathrm{~min}$ of stabilization, then 3-5 post-capillary venules are selected by their diameters (approximately $20 \mu \mathrm{m}$ ) and examined once. A charge-coupled device (CCD) color camera (TK-C1380U, JVC, Tokyo, Japan) is incorporated with a triple-ocular microscope (Axioplan 2, Zeiss, München, Germany), which sends the signal (magnification 1,960) to a computer monitor (SyncMaster 753DFX, Samsung, Manaus, Brazil). Analyses of leukocyte-endothelial interactions were performed with image acquisition and analysis software (Axiovision 4.1, Zeiss, München, Germany). We counted the number of rolling leukocytes as the number of white cells that passed a designated line perpendicular to the venular axis during a 10-min period. ${ }^{24-26,28} \mathrm{We}$ counted the number of adherent cells as the number of cells that remained stationary for $>30$ seconds on a $100-\mu \mathrm{m}$ segment of the venular endothelium during a 10 -min period. ${ }^{24-26,28} \mathrm{We}$ counted the number of migrated leukocytes as the number of cells accumulated at the connective tissue, adjacent to the chosen postcapillary venule, in a standard area of $5,000 \mu \mathrm{m} .{ }^{24-26}$

\section{Lung Histology}

At the end of the experiment, the animal was exsanguinated by cutting the abdominal aorta. The lungs were then gently inflated $(10 \mathrm{~mL} / \mathrm{kg})$, removed, and fixed with $10 \%$ formalin solution in sodium phosphate buffer $(0.2 \mathrm{~mol} / \mathrm{L}$, $\mathrm{pH}$ 7.2) for 24 hours. The lungs were ethanol dehydrated and embedded in paraffin. Three lung sections $(5 \mu \mathrm{m})$ were cut from the apex to the base and stained with hematoxylin and eosin. Examination, as previously reported, ${ }^{24,26}$ was performed by 2 observers. We attached a $10^{4} \mu \mathrm{m}^{2}, 100$-point grid to the ocular lens of the microscope (magnification 1,000), and randomly chose 12 20 fields in each section (3-5 per animal), then quantified the edema volume index (volume fraction of perivascular and interstitial edema divided by total perivascular tissue), the polymorphonuclear cell density (cells $/ 10^{4} \mu \mathrm{m}^{2}$ ) in the perivascular and interstitial tissue, and the polymorphonuclear cell density (cells $/ 10^{4} \mu \mathrm{m}^{2}$ ) in the alveolar septa.

\section{Statistical Analysis}

We chose the sample size for this study based on our previous experiments on mesenteric leukocyte-endothelial interactions. ${ }^{19,24-26} \mathrm{We}$ report the data as median and interquartile range (IQR). We compared the groups with the Kruskal-Wallis test, and tested differences between groups with the Dunn Test. We tested differences between periods with the Wilcoxon signed rank test. $P$ values $<.05$ were considered significant.

\section{Results}

\section{Hemodynamics}

Mean arterial blood pressure was similar at baseline and after 2 hours and also between groups: low $\mathrm{V}_{\mathrm{T}} 98.5 \mathrm{~mm} \mathrm{Hg}$ (IQR 94.0-108.3 $\mathrm{mm} \mathrm{Hg}$ ) and $98.0 \mathrm{~mm} \mathrm{Hg}$ (IQR 78.0$123.3 \mathrm{~mm} \mathrm{Hg}$ ), respectively; high $\mathrm{V}_{\mathrm{T}} 117.0 \mathrm{~mm} \mathrm{Hg}$ (IQR 94.3-131.5 $\mathrm{mm} \mathrm{Hg}$ ) and $107.5 \mathrm{~mm} \mathrm{Hg}$ (IQR 86.3$128.0 \mathrm{~mm} \mathrm{Hg}$ ), respectively; and high- $\mathrm{V}_{\mathrm{T}} /$ pentoxifylline $111.5 \mathrm{~mm} \mathrm{Hg}$ (IQR $92.3-119.5 \mathrm{~mm} \mathrm{Hg}$ ) and $106.0 \mathrm{~mm} \mathrm{Hg}$ (IQR 92.5-113.5 $\mathrm{mm} \mathrm{Hg}$ ), respectively. There were no significant differences in mesenteric blood flow between groups: low $\mathrm{V}_{\mathrm{T}} 15.1 \mathrm{~mL} / \mathrm{s}(\mathrm{IQR} 12.4-17.7 \mathrm{~mL} / \mathrm{s})$; high $\mathrm{V}_{\mathrm{T}}$ $11.3 \mathrm{~mL} / \mathrm{s}$ (IQR $8.6-13.8 \mathrm{~mL} / \mathrm{s}$ ); and high- $\mathrm{V}_{\mathrm{T}} /$ pentoxifylline $12.4 \mathrm{~mL} / \mathrm{s}$ (IQR $10.8-13.7 \mathrm{~mL} / \mathrm{s})$, respectively.

\section{Arterial Blood Gases and Lactate}

At baseline there were no significant differences between the groups in $\mathrm{pH}, \mathrm{P}_{\mathrm{aCO}_{2}}$, or lactate (Table 1). $\mathrm{P}_{\mathrm{aO}}$ was within normal range in all 3 groups, but was higher in the high $-\mathrm{V}_{\mathrm{T}}$ /pentoxifylline group than in the low- $\mathrm{V}_{\mathrm{T}}$ group. After 2 hours of mechanical ventilation, oxygenation increased in the low- $\mathrm{V}_{\mathrm{T}}$ group and high- $\mathrm{V}_{\mathrm{T}}$ group, and remained higher in the high- $\mathrm{V}_{\mathrm{T}}$ /pentoxifylline group. $\mathrm{P}_{\mathrm{aCO}}$ and $\mathrm{pH}$ were similar in all groups at baseline and at 2 hours. 
Low and High Tidal Volume Versus Pentoxifylline in Mechanically Ventilated Rats

Table 1. Arterial Blood Gas and Lactate Values*

\begin{tabular}{|c|c|c|c|c|c|}
\hline & $\begin{array}{l}\text { Time } \\
\text { Point }\end{array}$ & $\begin{array}{l}\text { Low } V_{\mathrm{T}} \\
(\text { no. }=6)\end{array}$ & $\begin{array}{l}\operatorname{High} V_{T} \\
(\text { no. }=7)\end{array}$ & $\begin{array}{l}\text { High } \mathrm{V}_{\mathrm{T}}+\text { Pentoxifylline } \\
(\text { no. }=5)\end{array}$ & $P$ \\
\hline \multirow[t]{2}{*}{$\mathrm{pH}$} & Baseline & 7.35 (7.26-7.38) & $7.34(7.31-7.35)$ & $7.36(7.35-7.38)$ & .33 \\
\hline & 2 hours & $7.27(7.25-7.32)$ & $7.31(7.29-7.35)$ & $7.26(7.25-7.36)$ & .46 \\
\hline \multirow[t]{2}{*}{$\mathrm{P}_{\mathrm{aO}_{2}}(\mathrm{~mm} \mathrm{Hg})$} & Baseline & $83(67-88)$ & $82(81-106)$ & $105(92-116) \dagger$ & .02 \\
\hline & 2 hours & $125(102-133) \ddagger$ & $118(111-139) \S$ & $105(88-119)$ & .26 \\
\hline \multirow[t]{2}{*}{$\mathrm{P}_{\mathrm{aCO}_{2}}(\mathrm{~mm} \mathrm{Hg})$} & Baseline & $41(36-47)$ & $48(42-49)$ & $43(41-44)$ & .47 \\
\hline & 2 hours & $52(42-57)$ & $45(41-50)$ & $46(41-60)$ & .18 \\
\hline \multirow[t]{2}{*}{ Lactate $(\mathrm{mmol} / \mathrm{L})$} & Baseline & $2.85(2.53-3.05)$ & $2.20(1.50-2.70)$ & $2.70(2.45-3.05)$ & .07 \\
\hline & 2 hours & $1.60(1.25-2.05) \|$ & $2.50(2.20-3.80) \mathbb{I}$ & $1.90(1.35-2.15)^{* *}$ & .02 \\
\hline \multicolumn{6}{|c|}{ 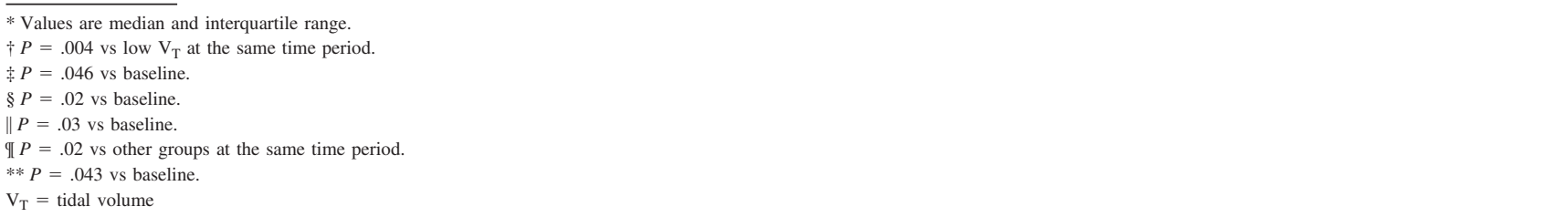 } \\
\hline
\end{tabular}

Table 2. Respiratory Mechanics Data*

\begin{tabular}{|c|c|c|c|c|c|}
\hline & Time Point & $\begin{array}{l}\text { Low } V_{\mathrm{T}} \\
\text { (no. }=6 \text { ) }\end{array}$ & $\begin{array}{l}\text { High } V_{T} \\
\text { (no. }=6 \text { ) }\end{array}$ & $\begin{array}{l}\text { High } \mathrm{V}_{\mathrm{T}}+\text { Pentoxifylline } \\
\text { (no. }=7)\end{array}$ & $P$ \\
\hline \multirow[t]{2}{*}{ Peak airway pressure $\left(\mathrm{cm} \mathrm{H}_{2} \mathrm{O}\right)$} & Baseline & $10.4(9.7-10.4)$ & $10.1(8.1-10.1) \dagger$ & $10.6(9.7-11.8)$ & .003 \\
\hline & 2 hours & $10.4(10.2-10.4) \ddagger \S$ & $12.6(10.2-14.9)$ & $12.8(10.7-16.0) \|$ & .03 \\
\hline \multirow[t]{2}{*}{ Elastance $\left(\mathrm{cm} \mathrm{H}_{2} \mathrm{O} / \mathrm{mL}\right)$} & Baseline & $3.8(3.6-3.8)$ & $3.4(3.3-3.4)$ & $3.97(3.1-4.8)$ & .58 \\
\hline & 2 hours & $3.8(3.8-3.8) \ddagger$ & $3.8(3.5-3.8) \|$ & $4.4(3.8-7.1) \mathrm{I}$ & .57 \\
\hline \multirow[t]{2}{*}{ Resistance $\left(\mathrm{cm} \mathrm{H}_{2} \mathrm{O} / \mathrm{mL} / \mathrm{s}\right)$} & Baseline & $0.2(0.2-0.2)$ & $0.2(0.2-0.2)$ & $0.2(0.2-0.2)$ & .99 \\
\hline & 2 hours & $0.2(0.2-0.2) \ddagger$ & $0.2(0.2-0.2) \|$ & $0.2(0.2-0.2) \|$ & .99 \\
\hline \multicolumn{6}{|c|}{ 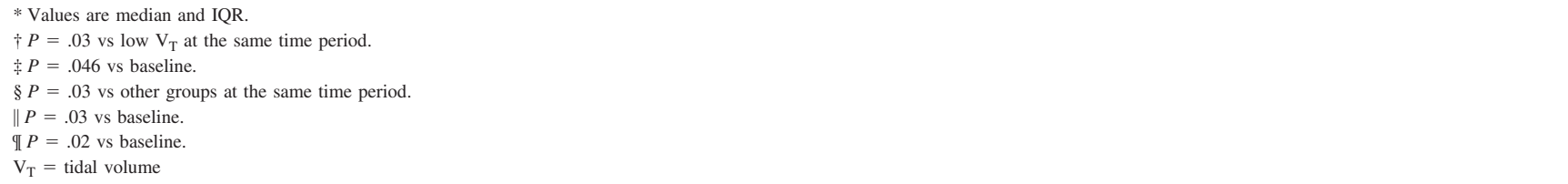 } \\
\hline
\end{tabular}

Lactate improved in the low- $\mathrm{V}_{\mathrm{T}}$ group and the high- $\mathrm{V}_{\mathrm{T}} /$ pentoxifylline group, compared to the high- $\mathrm{V}_{\mathrm{T}}$ group.

\section{Respiratory Mechanics}

Peak airway pressure was lower in the low- $\mathrm{V}_{\mathrm{T}}$ group than in the high $-\mathrm{V}_{\mathrm{T}}$ group or the high- $\mathrm{V}_{\mathrm{T}}$ /pentoxifylline group (Table 2). Respiratory system elastance increased and respiratory system resistance decreased in all 3 groups.

\section{Mesenteric Leukocyte-Endothelial Interactions}

Table 3 shows the microvessel diameter and leukocyte data. Figure 1 also shows the leukocyte data.

\section{Lung Neutrophil Infiltration and Edema}

There was no intra-alveolar hemorrhage or hyaline membrane in any of the groups. Table 4 shows the neutrophil infiltration in the alveolar septa and perivascular tissue, and edema in the perivascular tissue. Neutrophil infiltration in the perivascular and interstitial tissue was significantly higher in the high $-\mathrm{V}_{\mathrm{T}}$ group than in the low- $\mathrm{V}_{\mathrm{T}}$ group $(P<.001)$. Compared to the low- $\mathrm{V}_{\mathrm{T}}$ group and the high- $\mathrm{V}_{\mathrm{T}}$ /pentoxifylline group, the high- $\mathrm{V}_{\mathrm{T}}$ group had more neutrophil infiltration in the alveolar septa, which was associated with more interstitial and perivascular tissue edema (Fig. 2).

\section{Discussion}

Baseline oxygenation was higher in the high $-\mathrm{V}_{\mathrm{T}}$ group and the high $-\mathrm{V}_{\mathrm{T}}$ /pentoxifylline group than in the low- $\mathrm{V}_{\mathrm{T}}$ group. It appears that high- $\mathrm{V}_{\mathrm{T}}$ ventilation transiently increased oxygenation and caused inflammatory response at 2 hours, compared to low- $\mathrm{V}_{\mathrm{T}}$ ventilation. Early pentoxi- 
Table 3. Microvessel Diameters and Leukocyte Data*

\begin{tabular}{|c|c|c|c|}
\hline & $\begin{array}{l}\text { Low } \mathrm{V}_{\mathrm{T}} \\
\text { no. }=6\end{array}$ & $\begin{array}{l}\text { High } \mathrm{V}_{\mathrm{T}} \\
\text { no. }=7\end{array}$ & $\begin{array}{c}\text { High } \mathrm{V}_{\mathrm{T}} \text { Plus Pentoxifylline } \\
\text { no. }=5\end{array}$ \\
\hline Microvessel diameter $(\mu \mathrm{m})$ & $19(17-22)$ & $20(20-23)$ & $20(19-21)$ \\
\hline Rolling leukocytes (cells/10 min) & $139(106-165)$ & $195(182-234)$ & $185(159-196)$ \\
\hline Adherent leukocytes (cells/100 $\mu \mathrm{m}$ length) & $5(4-7)$ & $14(11-16)$ & $5(3-10)$ \\
\hline Migrated leukocytes to the perivascular tissue (cells $/ 5,000 \mu \mathrm{m}^{2}$ ) & $1(1-2)$ & $9(8-12)$ & $1(1-3)$ \\
\hline
\end{tabular}
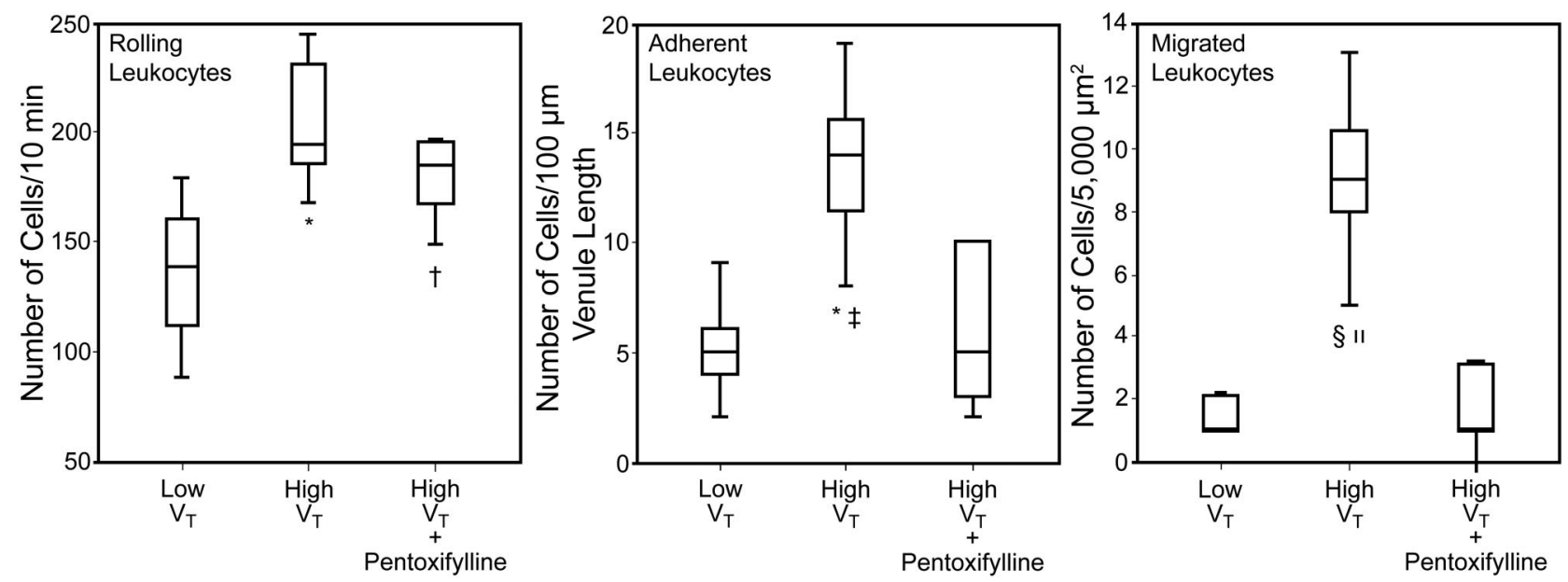

Fig. 1. Rolling leukocytes, adherent leukocytes, and migrated leukocytes in postcapillary venules in the mesentery of rats, after 2 hours of mechanical ventilation with either low tidal volume $\left(\mathrm{V}_{\mathrm{T}}\right)(n=6)$, high $\mathrm{V}_{\mathrm{T}}(n=7)$, or high $\mathrm{V}_{\mathrm{T}}$ plus early pentoxifylline $(n=5)$. * $P=.002$ versus low $\mathrm{V}_{\mathrm{T}} . \dagger P=.03$ versus high- $\mathrm{V}_{\mathrm{T}} /$ pentoxifylline. $\ddagger P=.01$ versus high- $\mathrm{V}_{\mathrm{T}}$ /pentoxifylline. $\S P=.001$ versus low $\mathrm{V}_{\mathrm{T}}$. $\| P=.003$ versus high- $\mathrm{V}_{\mathrm{T}} /$ pentoxifylline.

Table 4. Neutrophil Infiltration in the Alveolar Septa and Perivascular Tissue, and Edema in the Perivascular Tissue

\begin{tabular}{|c|c|c|c|}
\hline & \multirow{2}{*}{$\frac{\begin{array}{c}\text { Lung } \\
\text { Parenchyma }\end{array}}{\begin{array}{c}\text { Neutrophils } \\
\left(10^{4} / \mu \mathrm{m}^{2}\right)\end{array}}$} & \multicolumn{2}{|c|}{ Lung Perivascular Tissue } \\
\hline & & Edema Index & $\begin{array}{c}\text { Neutrophils } \\
\left(10^{4} / \mu \mathrm{m}^{2}\right)\end{array}$ \\
\hline Low $\mathrm{V}_{\mathrm{T}}($ no. $=6)$ & $0(0-25)$ & $0.42(0.09-0.91)$ & $0(0-7)$ \\
\hline High $\mathrm{V}_{\mathrm{T}}($ no. $=6)$ & $9(0-33)^{*}$ & $0.74(0.25-1.00)^{*}$ & $0(0-18) \dagger$ \\
\hline $\begin{array}{l}\text { High } V_{\mathrm{T}}+ \\
\text { pentoxifylline (no. }=7)\end{array}$ & $0(0-22)$ & $0.50(0.07-0.88)$ & $0(0-20)$ \\
\hline $\begin{array}{l}\text { *P } P<.001 \text { vs other groups. } \\
\dagger P<.001 \text { vs low } \mathrm{V}_{\mathrm{T}} . \\
\mathrm{V}_{\mathrm{T}}=\text { tidal volume }\end{array}$ & & & \\
\hline
\end{tabular}

fylline helped maintain oxygenation, perhaps because pentoxifylline's mild vasodilation properties improved gas exchange by the capillaries.

Early pentoxifylline appeared to reduce the inflammatory response from ventilator-induced lung injury. Most patients with acute lung injury require mechanical venti- lation, which can cause lung injury, and high ventilator settings are associated with a mortality rate of $35-65 \%$ in acute respiratory distress syndrome, usually from progressive dysfunction of vital organs. ${ }^{29,30}$ Several studies have shown an association between mechanical ventilation and exacerbated pulmonary inflammatory response and increased alveolar capillary permeability. ${ }^{1-3,31}$ Other studies have found protective effects from PEEP and low $\mathrm{V}_{\mathrm{T}}$ in patients with injured lungs ${ }^{1,3,32-34}$ and non-injured lungs. ${ }^{35}$ Recently, Dos Santos et al ${ }^{32}$ reported a $20-40 \%$ deterioration of pulmonary compliance in rats ventilated with a high $\mathrm{V}_{\mathrm{T}}(12 \mathrm{~mL} / \mathrm{kg})$, versus low $\mathrm{V}_{\mathrm{T}}(6 \mathrm{~mL} / \mathrm{kg})$, after 2-4 hours of mechanical ventilation. They demonstrated that acute ventilator-induced lung injury can be biochemically and biophysically distinguished early in the progression of the injury, with microarray and bioinformatic techniques. In the present study, the rats had an increase in peak airway pressure (approximately 15\%), a decrease in resistance (approximately 10\%), and a substantial increase in elastance (approximately 22\%). Lung injury was marked in the high- $\mathrm{V}_{\mathrm{T}}$ group, as indicated by more edema and 


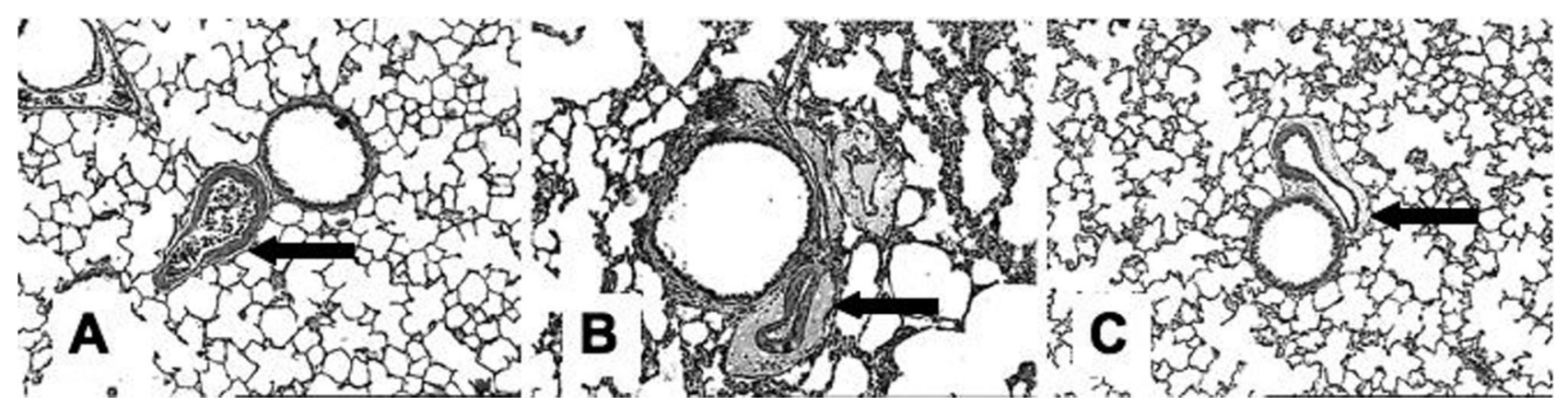

Fig. 2. Representative photomicrographs of rat lung. The vessels are branches of the pulmonary artery at the terminal bronchiolar level, and are of the same magnitude. The arrows point to edema in the perivascular and interstitial tissue. A: Low tidal volume $\left(\mathrm{V}_{\mathrm{T}}\right)$. $\mathrm{B}$ : High $\mathrm{V}_{\mathrm{T}}$. $\mathrm{C}$ : High $\mathrm{V}_{\mathrm{T}}$ plus early pentoxifylline. There is more edema in the perivascular and interstitial tissue in the high- $\mathrm{V}_{\mathrm{T}}$ group than in the low- $\mathrm{V}_{\mathrm{T}}$ or high- $\mathrm{V}_{\mathrm{T}}$ /pentoxifylline groups. Magnification 100, hematoxylin and eosin stain.

neutrophils in the parenchyma and perivascular tissue. In contrast, low $\mathrm{V}_{\mathrm{T}}$ induced only small amounts of neutrophil infiltration and edema. Similarly, early pentoxifylline attenuated ventilator-induced lung injury. Our results are consistent with those from Lessa et al, ${ }^{36}$ that pentoxifylline decreases inflammatory lung injury in rats mechanically ventilated with $\mathrm{V}_{\mathrm{T}}$ of $20 \mathrm{~mL} / \mathrm{kg}$, and from Yada-Langui et $\mathrm{al},{ }^{19}$ who found that pentoxifylline attenuated lung inflammatory response in a hemorrhagic shock/reperfusion rat model.

Microcirculatory integrity has a key role in adequate tissue oxygenation and organ function, which may be crucial in the prognosis of critically ill patients. ${ }^{11-13}$ Leukocytes circulate in the bloodstream and migrate into the tissues in response to signals released in the microenvironment of infection and tissue injury. Leukocyte-endothelial interactions are essential for effective defense from bacterial invasion. However, leukocyte over-activation and increased leukocyte accumulation in the perivascular tissue can be associated with an exaggerated pro-inflammatory immune response that can contribute to widespread microvascular injury and consequent endothelial damage. ${ }^{7,24-26}$ Hypoperfusion of the gastrointestinal vascular bed has been suggested as a potential mechanism for the development of several complications from mechanical ventilation in critically ill patients. ${ }^{8-10} \mathrm{We}$ recently found that high intrathoracic pressure generated by high $\mathrm{V}_{\mathrm{T}}$ $(10 \mathrm{~mL} / \mathrm{kg})$ and high PEEP $\left(10 \mathrm{~cm} \mathrm{H}_{2} \mathrm{O}\right)$ increased leukocyte-endothelial interactions in rat mesentery, as compared to PEEP values of 0 and $5 \mathrm{~cm} \mathrm{H}_{2} \mathrm{O}$, with no significant differences in mean arterial blood pressure between the groups. ${ }^{26}$ In the present study we used that same rat model and found that high $\mathrm{V}_{\mathrm{T}}$ and high PEEP had similar deleterious effects on mesenteric leukocyte-endothelial interactions.

We choose PEEP of $10 \mathrm{~cm} \mathrm{H}_{2} \mathrm{O}$, because in a separate study (unpublished data) with surfactant-depleted rats we found that both maximum lung compliance and oxygenation were achieved at a PEEP of $12 \mathrm{~cm} \mathrm{H}_{2} \mathrm{O}$, whereas the rats in the present study had healthy lungs. In healthy anesthetized piglets, PEEP of $16 \mathrm{~cm} \mathrm{H}_{2} \mathrm{O}$ resulted in hyperinflation that decreased when PEEP was progressively reduced to around $10 \mathrm{~cm} \mathrm{H}_{2} \mathrm{O} .{ }^{37}$ Because of the severity of the underlying disease, in many patients it is not possible to provide a ventilation strategy that will protect all lung units, so a pharmacologic therapy that modulates the inflammatory response would be beneficial.

A novel finding of the present study is that, compared to high $\mathrm{V}_{\mathrm{T}}$, low $\mathrm{V}_{\mathrm{T}}$ attenuates over-activation and leukocyte accumulation in the mesenteric perivascular tissue, without affecting lung elastance. This suggests that lung injury and acute inflammatory response start early in mechanical ventilation, prior to alteration of lung mechanics. In addition, pentoxifylline attenuates leukocyte-endothelial interactions at the mesentery after 2 hours of mechanical ventilation with high $\mathrm{V}_{\mathrm{T}}$ and high PEEP. Taken together, these results show systemic inflammation induced by alveolar overdistention during high $\mathrm{V}_{\mathrm{T}}$ and suggest that low $\mathrm{V}_{\mathrm{T}}$ prevents mesenteric microcirculatory derangements, and that pentoxifylline during high $\mathrm{V}_{\mathrm{T}}$ modulates adherence and migration at the mesentery and improves blood lactate. These pentoxifylline benefits were probably related to reduced lactate production, antithrombotic activity, ${ }^{38}$ increase red-blood-cell deformability, ${ }^{13}$ and attenuation of the inflammatory response. ${ }^{18,39,40}$

\section{Limitations}

To access the mesenteric microcirculation we performed a midline abdominal incision to expose the mesentery for intravital microscopy and the mesenteric artery for flow measurements. This could, in principle, interfere with the microcirculation. However, the abdomen was kept closed during the study period and during all the other measurements. One could argue that PEEP decreases intestinal blood flow in proportion to the applied PEEP level, as previously reported. ${ }^{5,6} \mathrm{We}$ did not measure intrapulmonary pressure. However, we set PEEP at $10 \mathrm{~cm} \mathrm{H}_{2} \mathrm{O}$ in all 


\section{Low and High Tidal Volume Versus Pentoxifylline in Mechanically Ventilated Rats}

the animals, and despite differences between the groups in respiratory rate $\left(80\right.$ breaths/min in the low- $\mathrm{V}_{\mathrm{T}}$ group vs 70 breaths/min in the high $-\mathrm{V}_{\mathrm{T}}$ and high- $\mathrm{V}_{\mathrm{T}} /$ pentoxifylline groups) and $\mathrm{V}_{\mathrm{T}}\left(7 \mathrm{~mL} / \mathrm{kg}\right.$ in the low- $\mathrm{V}_{\mathrm{T}}$ group vs $10 \mathrm{~mL} / \mathrm{kg}$ in the high $\mathrm{V}_{\mathrm{T}}$ and high- $\mathrm{V}_{\mathrm{T}}$ /pentoxifylline groups), the mean arterial blood pressure and mesenteric blood flow were not different between the groups, which suggests a blood-flow-independent inflammatory response as a result of biotrauma during mechanical ventilation. A likely explanation is inflammatory mediator translocation from pulmonary to systemic circulation following mechanical ventilation.

Another limitation is that we did not measure adhesion molecules. However, we previously found positive correlations between the expression of P-selectin and intercellular molecules with leukocyte-endothelial interactions at the mesentery and lungs after hemorrhagic shock/reperfusion and sepsis. ${ }^{7,19,24}$ And in the present study we found significant differences in leukocyte-endothelial interactions between the groups, which were not associated with hemodynamics. The increased leukocyte adhesion and migration to the perivascular tissue at the mesentery (distant locale) may have been induced by systemic inflammation biotrauma, which was prevented by low $\mathrm{V}_{\mathrm{T}}$ and attenuated by pentoxifylline. Moreover, our findings were obtained in rats with normal lungs submitted to 2 hours of mechanical ventilation, and we must be very cautious in interpreting the data relative to mechanically ventilated patients.

\section{Conclusions}

Two hours of mechanical ventilation with high $\mathrm{V}_{\mathrm{T}}$ and high PEEP were harmful to mesenteric microcirculation and the lungs of rats, whereas low $\mathrm{V}_{\mathrm{T}}$ with high PEEP protected the lungs and mesenteric microcirculation, and early pentoxifylline attenuated lung and mesenteric inflammation during high $\mathrm{V}_{\mathrm{T}}$ and high PEEP. These findings suggest that early pentoxifylline might decrease the risk of ventilator-induced microcirculatory derangements and lung injury.

\section{ACKNOWLEDGMENTS}

We thank Julia Fukushima for help with statistical analysis. The platform for intravital microscopic study of the rat mesentery was developed by Naomi Kondo Nakagawa, Simão Bacht, and Idágene Cestari.

\section{REFERENCES}

1. Brower RG, Matthay MA, Morris A, Schoenfeld D, Thompson BT, Wheeler A; on behalf of the Acute Respiratory Distress Syndrome Network. Ventilation with lower tidal volumes as compared with traditional tidal volumes for acute lung injury and the Acute Respiratory Distress Syndrome. N Engl J Med 2000;342(18):1301-1308.

2. Antonelli M, Azoulay E, Bonten M, Chastre J, Citerio G, Conti G, et al. Year in review in Intensive Care Medicine, 2008: II. Experimen- tal, acute respiratory failure and ARDS, mechanical ventilation and endotracheal intubation. Intensive Care Med 2009;35(2):215-231.

3. Ko SC, Zhang H, Haitsma JJ, Cheng KC, Li CF, Slutsky AS. Effects of PEEP levels following repeated recruitment maneuvers on ventilator-induced lung injury. Acta Anaesthesiol Scand 2008;52(4):514521.

4. Dorinsky PM, Whitcomb ME. The effect of PEEP on cardiac output. Chest 1983;84(2):210-216.

5. Lehtipalo S, Biber B, Frojse R, Arnerlöv C, Johansson G, Winsö O. Effects of PEEP on intestinal circulation during graded mesenteric artery occlusion. Acta Anaesthesiol Scand 2001;45(7):875-884.

6. Love R, Choe E, Lippton H, Flint L, Steinberg S. Positive endexpiratory pressure decreases mesenteric blood flow despite normalization of cardiac output. J Trauma 1995;39(2):195-199.

7. Zanoni FL, Benabou S, Greco KV, Moreno ACR, Costa Cruz JWM, Filgueira FP, Martinez MB, et al. Mesenteric microcirculatory dysfunctions and translocation of indigenous bacteria in a rat model of strangulated small bowel obstruction. Clinics 2009;64(9):911-919.

8. Cook DJ, Heyland D, Griffith L, Cook R, Marshall J, Pagliarello J. Risk factors for clinically important upper gastrointestinal bleeding in patients requiring mechanical ventilation: Canadian Critical Care Trials Group. Crit Care Med 1999;27:2812-2817.

9. Mutlu GM, Mutlu EA, Factor P. GI complications in patients receiving mechanical ventilation. Chest 2001;119(4):1222-1241.

10. Spirt MJ, Guth PH, Randall G, Leung FW. Gastroduodenal perfusion and mortality in mechanical ventilation-dependent patients with systemic inflammatory response syndrome. Digest Dis Sciences 2004; 49(6):906-913.

11. Trzeciak S, Dellinger P, Parrillo JE, Guglielmi M, Bajaj J, Abate NL, et al. Early microcirculatory perfusion derangements in patients with severe sepsis and septic shock: relationship to hemodynamics, oxygen transport, and survival. Ann Emerg Med 2007;49(1):88-98.

12. De Backer D, Creteur J, Dubois MJ, Sakr Y, Vincent JL. Microvascular alterations in patients with acute severe heart failure and cardiogenic shock. Am Heart J 2004;147(1):91-99.

13. Sakr Y, Dubois MJ, De Backer D, Creteur J, Vincent JL. Persistent microcirculatory alterations are associated with organ failure and death in patients with septic shock. Crit Care Med 2004;32(9):18251831.

14. Ohshima N, Sato M. Effect of pentoxifylline on microvascular blood flow velocity. Angiology 1981;32(11):752-763.

15. Bacher A, Eggensperger E, Koppensteiner R, Mayer N, Klimscha W. Pentoxifylline attenuates the increase in whole blood viscosity after transfusion. Acta Anaesthesiol Scand 2005;49(1):41-46.

16. Pawlik MT, Schreyer AG, Ittner KP, Selig C, Gruber M, Feuerbach $\mathrm{S}$, Taeger K. Early treatment with pentoxifylline reduces lung injury induced by acid aspiration in rats. Chest 2005;127(2):613-621.

17. Korhonen K, Kiuru A, Svedstrom E, Kaapa P. Pentoxifylline reduces regional inflammatory and ventilatory disturbances in meconiumexposed piglet lungs. Pediatr Res 2004;56(6):901-906.

18. Flynn WJ, Cryer HG, Garrison RN. Pentoxifylline restores intestinal microvascular blood flow during resuscitated hemorrhagic shock. Surgery 1991;110(2):350-356.

19. Yada-Langui MM, Anjos-Valotta EA, Sannomiya P, Rocha e Silva M, Coimbra R. Resuscitation affects microcirculatory polymorphonuceat leukocyte behavior after hemorrhagic chock: role of hypertonic saline and pentoxifylline. Exp Biol Med 2004;229(7):684-693.

20. Campos T, Deree J, Martins JO, Loomis WH, Shenvi E, Putnam JG, Coimbra R. Pentoxifylline attenuates pulmonary inflammation and neutrophil activation in experimental acute pancreatitis. Pancreas 2008;37(1):42-49.

21. Marques LJ, Zheng L, Poulakis N, Guzman J, Costabel U. Pentoxifylline inhibits TNF- $\alpha$ production from human alveolar macrophages. Am J Respir Crit Care Med 1999;159(2):508-511. 


\section{Low and High Tidal Volume Versus Pentoxifylline in Mechanically Ventilated Rats}

22. Volman TJ, Goris RJ, Hendriks T. Pentoxifylline does not improve outcome in a murine model for the multiple-organ dysfunction syndrome. Intensive Care Med 2005;31(5):701-708.

23. Staudinger T, Presterl E, Graninger W, Locker GP, Knapp S, Laczika $\mathrm{K}$, et al. Influence of pentoxifylline on cytokine levels and inflammatory parameters in septic shock. Intensive Care Med 1996; 22(9):888-893.

24. Nakagawa NK, Nogueira RA, Correia CJ, Shiwa SR, Costa Cruz JW, Poli de Figueiredo LF, et al. Leukocyte-endothelium interactions after hemorrhagic shock/reperfusion and cecal ligation/puncture: an intravital microscopic study in rat mesentery. Shock 2006; 26(2): 180-186.

25. Nakagawa NK, Jukemura J, Aikawa P, Shiwa SR, Costa Cruz JW, Poli de Figueiredo LF, et al. In vivo observation of mesenteric leukocyte-endothelial interactions after cecal ligation/puncture and surgical source. Clinics 2007;62(3):321-326.

26. Aikawa P, Farsky SHP, Oliveira MA, Pazetti R, Mauad T, Sannomiya P, Nakagawa NK. Effects of different PEEP levels during mechanical ventilation on mesenteric leukocyte-endothelial interactions in rats. Clinics 2009;64(5):443-450.

27. Prado CM, Leick-Maldonado EA, Yano L, Leme AS, Capelozzi VL, Martins MA, Tibério IF. Effects of nitric oxide synthases in chronic allergic airway inflammation and remodeling. Am J Respir Cell Mol Biol 2006;35(4):457-465.

28. Kubes P, Heit B, Van Marle G, Johnston JB, Knight D, Khan A, Power C. In vivo impairment of neutrophil recruitment during lentivirus infection. J Immunol 2003;171(9):4801-4808.

29. American Thoracic Society, European Society of Intensive Care Medicine, Societé de Réanimation Langue Française. International consensus conferences in intensive care medicine: ventilator-associated lung injury in ARDS. Intensive Care Med 1999;25(12):1444-1452.

30. Zhang H, Downey GP, Suter P, Slutsky AS, Ranieri VM. Conventional mechanical ventilation is associated with bronchoalveolar lavage-induced activation of polymorphonuclear leukocytes: a possible mechanism to explain the systemic consequences of ventilatorinduced lung injury in patients with ARDS. Anesthesiology 2002; 97(6):1426-1433.
31. Haitsma JJ, Uhlig S, Goggel R, Verbrugge SJ, Lachmann U, Lachmann B. Ventilator-induced lung injury leads to loss of alveolar and systemic compartmentalization of tumor necrosis factor-alpha. Intensive Care Med 2000;26(10):1515-1522.

32. Dos Santos CC, Okutani D, Hu P, Han B, Crimi E, He X, et al. Differential gene profiling in acute lung injury identifies injuryspecific gene expression. Crit Care Med 2008;36(3):855-865.

33. Amato MBP, Barbas CSV, Medeiros DM, Magaldi RB, Schettino GPP, Lorenzi-Filho G, et al. Effect of a protective-ventilation strategy on mortality in the acute respiratory distress syndrome. N Engl J Med 1998;338(6):347-354.

34. Villar J, Kacmarek RM, Pérez-Méndez L, Aguirre-Jaime A. A high positive end-expiratory pressure, low tidal volume ventilatory strategy improves outcome in persistent acute respiratory distress syndrome: a randomized controlled trial. Crit Care Med 2006;34(5): 1311-1318.

35. Schultz MJ, Haitsma JJ, Slutsky AS, Gajic O. What tidal volumes should be used in patients without acute lung injury? Anesthesiology 2007;106(6):1226-1231.

36. Lessa A, Suguihara C, Xianyu S, Hehre D, Devia C, Bancalari E. The effect of pentoxifylline on the pulmonary response to high tidal volume ventilation in rats. Pulm Pharmacol Ther 2008;21(1):54-60.

37. Carvalho ARS, Jandre FC, Pino AV, Bozza FA, Salluh JI, Rodrigues RS, et al. Effects of descending positive end-expiratory pressure on lung mechanics and aeration in healthy anaesthetized piglets. Crit Care 2006;10(4):R122.

38. Schroer RH. Antithrombotic potential of pentoxifylline. A hemorheologically active drug. Angiology 1985;36(6):387-398.

39. Bahra PS, Rainger GE, Wautier JL, Nash GB. Effects of pentoxifylline on the different steps during adhesion and transendothelial migration of flowing neutrophils. Cell Biochem Funct 2001;19(4): 249-257.

40. Dominguez-Jimenez C, Sancho D, Nieto M, Montoya MC, Barreiro O, Sanchez-Madrid F, Gonzalez-Amaro R. Effect of pentoxifylline on polarization and migration of human leukocytes. J Leukocyte Biol 2002;71(4):588-596 